\title{
EFEKTIFITAS MODEL PEMBELAJARAN PERUBAHAN KONSEPTUAL UNTUK MENGATASI MISKONSEPSI FISIKA PADA SISWA KELAS X SMAN 1 PRAYA BARAT TAHUN PELAJARAN 2012/2013
}

\author{
Dwi Pebriyanti' ${ }^{1}$, Hairunnisyah Sahidu², Sutrio $^{2}$ \\ 1) Program Studi Pendidikan Fisika \\ 2) Program Studi Pendidikan Fisika FKIP \\ Universitas Mataram \\ Mataram, Indonesia \\ Email : dwipebriyanti.physic@gmail.com
}

\begin{abstract}
This research is a pre-experimental research with one group pretest - posttest design. The aim of this research is to know the efectivity of the conceptual changes model to solve the physics misconception of students in grade X SMAN 1 Praya Barat for academic year 2012/2013. The population is all of the students grade X SMAN 1 Praya Barat, it is 273 students and the sample is grade X.6, its 33 students that taking by using purposive sampling technique. The misconception data analized using gain value and $\mathrm{N}$-gain. We get gain value $(\mathrm{G}) 17,5 \%$ and $\mathrm{N}$-gain $<\mathrm{g}>0,65$ with medium criteria. It's mean that the conceptual changes model is efective to solve the student misconception in grade X SMAN 1 Praya Barat with medium criteria.
\end{abstract}

Keywords: the changes conceptual model, misconception.

\section{Pendahuluan}

Mata pelajaran fisika pada jenjang SMA memiliki beberapa tujuan, diantaranya adalah agar siswa memiliki kemampuan: (1) Mengembangkan kemampuan bernalar dalam berpikir analisis induktif dan deduktif dengan menggunakan konsep dan prinsip fisika untuk menjelaskan berbagai peristiwa alam dan penyelesaian masalah baik secara kualitatif maupun kuantitatif (2) Menguasai konsep dan prinsip fisika serta mempunyai keterampilan mengembangkan pengetahuan, dan sikap percaya diri sebagai bekal untuk melanjutkan pendidikan pada jenjang yang lebih tinggi serta mengembangkan ilmu pengetahuan dan teknologi [1].

Merujuk pada tujuan diatas tampak bahwa pemahaman konsep bagi siswa sangatlah penting sebagai dasar untuk melanjutkan pendidikan kejenjang yang lebih tinggi dan sebagai bekal untuk diterapkan dalam kehidupan sehari-hari juga pemahaman konsep sangat diperlukan seorang siswa untuk menyelesaikan permasalahan dalam kehidupannya.

Miskonsepsi pada siswa harus diatasi sedini mungkin, sebab kesalahan konsep akan menyebabkan kesalahan-kesalahan pemahaman pada konsep berikutnya dan juga dapat mengganggu proses penyelesaian masalah dan identifikasi contoh-contoh fenomena fisika dalam kehidupan sehari-hari. Salah satu cara untuk mengatasi miskonsepsi fisika siswa adalah dengan menerapkan model pembelajaran perubahan konseptual, karena model pembelajaran ini menjembatani kesenjangan antara pengetahuan tentang fenomena keseharian dan konsep yang benar secara sains dengan menghadirkan konflik kognitif sehingga siswa dapat merubah konsepnya yang salah dan mengakomodasi konsep yang tepat secara ilmiah.

Kedepan peneliti berharap penelitian ini dapat dijadikan alternative model pembelajaran untuk mengatasi miskonsepsi fisika pada siswa.

\section{TinjauAn PUSTAKa}

\section{A. Model Pembelajaran Perubahan Konseptual}

Siswa mengawali belajar disekolah tidak seperti kertas kosong, karena belajar tidak hanya dimulai dari bangku sekolah melainkan sejak lahir dan sejak berinteraksi dengan lingkungannya, sehingga pada saat mulai belajar disekolah siswa sudah memiliki gagasan yang terbentuk pada berbagai topik, termasuk bagaimana mereka melihat dan menafsirkan tentang dunia sekitar mereka. Beberapa gagasan tersebut sejalan dengan konsep ilmiah tetapi beberapa gagasan juga berbeda [2].

Dalam belajar ada dua proses belajar yaitu asimilasi dan akomodasi. Pada asimilasi, siswa menggunakan konsep-konsep yang telah ada untuk menghadapi suatu gejala baru dengan suatu perubahan kecil yang berupa penyesuaian, dalam hal ini konsep awal siswa tidak salah hanya saja kurang lengkap, maka mereka harus mengembangkan konsep awalnya menjadi lebih lengkap dan utuh. Pada akomodasi siswa harus mengubah konsep awalnya karena tidak dapat menjelaskan atau menjawab gejala baru, sehingga siswa harus melepas konsep awalnya dan membentuk konsep baru yang dapat digunakan 
dalam menghadapi permasalahan tersebut. Agar terjadi perubahan konsep atau akomodasi dibutuhkan beberapa keadaan dan syarat seperti berikut:

1. Siswa tidak puas terhadap konsep awalnya. Siswa akan mengubah konsepnya jika mereka yakin bahwa konsep mereka yang lama tidak dapat digunakan lagi untuk menelaah permasalahan dan fenomena baru.

2. Konsep baru harus dimengerti, rasional dan dapat memecahkan permasalahan dan fenomena baru.

3. Konsep baru harus dapat memecahkan dan menyelesaikan permasalahan yang dahulu, dan juga konsisten dengan teori-teori atau pengetahuan yang sudah ada sebelumnya.

4. Konsep baru harus berguna bagi perkembangan penelitian dan penemuan yang baru [3].

Perubahan konsep akan terjadi apabila siswa dihadapkan pada keadaan tidak seimbang yaitu ketidak cocokan antara konsep yang mereka miliki dengan keadaan lingkungan sekitarnya, sehingga menimbulkan konflik dalam pikiran mereka. Bila terjadi ketidak seimbangan maka siswa dipacu untuk mencari keseimbangan (equilibrium) dengan jalan akomodasi. Proses equilibrium akan membuat siswa menyatukan antara pengalaman luar dengan pengetahuannya dan konsep baru pun akan muncul. Bila siswa sudah dalam keadaan seimbang berarti siswa tersebut sudah berada pada tingkat intelektual yang lebih tinggi daripada sebelumnya [4].

Salah satu cara untuk memunculkan ketidak puasan itu menurut Posner et al. adalah dengan menyajikan peristiwa anomali yaitu suatu peristiwa yang bertentangan dengan konsep yang dimiliki siswa. Suatu peristiwa dimana siswa tidak dapat mengasimilasi pengetahuan untuk memahami fenomena yang baru. Banyak pendidik sains menggunakan data anomali untuk memacu perubahan konsep pada siswa, meskipun terkadang data anomali ini juga bisa gagal merubah konsep siswa karena siswa mengabaikannya [3].

"Dalam kondisi konflik kognitif siswa dihadapkan pada tiga pilihan, yaitu 1) mempertahankan intuisinya semula 2) merevisi sebagian intuisinya melalui proses asimilasi 3) merubah pandangannya yang bersifat intuisi tersebut dan mengakomodasi pengetahuan baru. Perubahan konseptual terjadi ketika siswa memutuskan pada pilihan ketiga"[5].

Posner et al. dalam [2] mengemukakan suatu pembelajaran yang melibatkan perubahan konsep seseorang disamping menambah pengetahuan baru dengan pengetahuan yang dimilikinya disebut model perubahan konseptual. Model ini berlandaskan paradigma konstruktivisme, membantu siswa untuk menjembatani kesenjangan antara pengetahuan tentang fenomena keseharian dan konsep-konsep yang benar secara sains.

Penelitian yang berkaitan dengan perubahan konseptual siswa sudah dimulai pada awal tahun 1980-an oleh Posner, et al. yaitu kelompok peneliti sains dan ahli psikologi di Universitas Cornell. Hasilhasil penelitian tentang model perubahan konseptual sebagai upaya menanggulangi konsepsi alternatif telah banyak disarankan oleh para ahli, maka guru hendaknya menerapkan model pembelajaran perubahan konseptual dalam pembelajaran agar dapat mengatasi miskonsepsi siswa.

"Model perubahan konseptual memandang proses belajar sebagai hal yang diskontinu dalam penyusunan ide-ide hingga memperoleh konsep yang baru". Model pembelajaran perubahan konseptual yang mendasarkan diri pada faham konstruktivisme, sesungguhnya adalah pembelajaran yang berbasis keterampilan berfikir. Pembelajaran perubahan konseptual memfasilitasi siswa untuk berpartisipasi aktif dalam mengkonstruksi pengetahuannya [5], sebab perubahan konseptual terjadi jika siswa aktif berinteraksi dengan lingkungannya. Dalam proses konstruksi pengetahuan, siswa menguji dan mereview ide-idenya berdasarkan pengetahuan awal yang telah dimiliki, menerapkannya dalam situasi yang baru, dan mengintegrasikan pengetahuan tersebut ke struktur kognitif yang dimiliki [3].

Konstruktivisme dan model perubahan konsep memberikan penjelasan bahwa setiap orang dapat membentuk pengertian yang berbeda dengan pengertian ilmiah. Namun pengertian yang berbeda tersebut bukanlah akhir perkembangan, karena setiap saat siswa masih bisa mengubah pengertiannya sehingga sesuai dengan pengertian ilmiah. Model perubahan konseptual ini sangat membantu karena mendorong pendidik agar menciptakan suasana dan keadaan untuk memungkinkan perubahan yang kuat pada siswa sehingga pemahaman mereka lebih sesuai dengan pemahaman ilmuan.

Model pembelajaran perubahan konseptual memiliki enam langkah pembelajaran yaitu: sajian masalah konseptual dan kontekstual, (2) konfrontasi miskonsepsi terkait dengan masalahmasalah tersebut, (3) konfrontasi sangkalan berikut strategi-strategi demonstrasi,analogi,atau contohcontoh tandingan, (4) konfrontasi pembuktian konsep dan prinsip secara ilmiah, (5) konfrontasi materi dan contoh-contoh kontekstual,(6) konfrontasi pertanyaan-pertanyaan untuk memperluas pemahaman dan penerapan pengetahuan secara bermakna [5].

Model pembelajaran perubahan konseptual membuat siswa lebih memahami konsep secara 
mendalam agar dapat bermanfaat bagi kehidupannya. Model ini menuntut guru lebih banyak berperan sebagai pengarah pembentukan konsep ilmiah, sehingga guru lebih banyak berperan sebagai fasilitator, negosiator dan konfrontator.

Pembelajaran perubahn konseptual memiliki empat variabel yang potensial dalam pembelajaran fisika, keempat variabel tersebut tertuang dalam strategi konflik kognitif dengan menerapkan strategistrategi demonstrasi/eksperimen, analogi, konfrontatif dan penyajian contoh-contoh tandingan [6].

\section{B. Miskonsepsi Fisika}

Walaupun dalam fisika kebanyakan konsep telah mempunyai arti yang jelas dan telah disepakati oleh para tokoh fisika, akan tetapi para siswa cenderung memiliki konsepsi fisika yang berbeda satu dengan yang lainnya. Beberapa siswa memiliki konsep fisika yang berbeda dengan konsep fisikawan; konsep fisikawan biasanya lebih kompleks, lebih rumit, dan lebih banyak melibatkan keterkaitan antar konsep. Apabila konsep fisika siswa ternyata sama dengan konsep fisikawan yang telah disederhanakan, maka konsep fisika siswa tersebut dikatakan benar. Sedangkan bila konsep fisika siswa bertentangan dengan konsep fisikawan yang telah disederhanakan maka siswa tersebut dikatakan mengalami kesalahan konsepi fisika atau miskonsepsi fisika [7].

"Miskonsepsi adalah pengertian yang tidak akurat akan konsep, penggunaan konsep yang salah, klasifikasi contoh-contoh yang salah, kekacauan konsep-konsep yang berbeda dan hubungan hierarkis konsep- konsep yang tidak benar"[8].

Miskonsepsi fisika dapat dinyatakan sebagai konsep fisika siswa yang tidak cocok dengan konsep fisikawan yang disederhanakan, hanya dapat diterima dalam kasus-kasus tertentu dan tidak berlaku untuk kasus-kasus lainnya, tidak dapat digeneralisasi dan tidak menunjukkan hubungan antar konsep-konsep fisika.

\section{Metode Penelitian}

Jenis penelitian yang digunakan dalam penelitian ini adalah pre-experimental desain dengan rancangan one-group pretest-postest desain, yaitu memberikan pretest kemudian memberikan perlakuan secara sengaja dan sistematis kepada suatu kelompok yaitu berupa perlakuan pembelajaran melalui model pembelajaran perubahan konseptual, dan pada akhir pembelajaran diberi postest.

Variabel bebas pada penelitian ini adalah model pembelajaran perubahan konseptual, sedangkan variabel terikatnya adalah miskonsepsi fisika siswa pada materi suhu dan kalor. Penelitian ini dilakukan di SMA Negeri 1 Praya Barat pada kelas X dari bulan
Oktober 2012 sampai Mei 2013. Populasi penelitian adalah seluruh siswa kelas X SMA Negeri 1 Praya Barat. Sampel penelitan yaitu kelas X.6 yang diambil dengan teknik purposive sampling.

Instrumen penelitian yang digunakan pada penelitian ini adalah Tes diagnostik pilihan ganda beralasan yang telah diuji pakar. Selanjutnya data miskonsepsi fisika dianalisis menggunakan nilai $\mathrm{N}$ gain yang dinormalisasi.

$$
<g>=\frac{T_{2}-T_{1}}{I_{S}-T_{1}}
$$

$$
\begin{aligned}
& \text { Keterangan: } \\
& \begin{aligned}
\langle\mathrm{g}\rangle & =\text { Nilai gain yang dinormalisasi } \\
\mathrm{T}_{1} & =\text { Skor pre-test } \\
\mathrm{T}_{2} & =\text { Skor post-test } \\
\mathrm{Is} & =\text { Skor ideal }
\end{aligned}
\end{aligned}
$$

\section{HASIl dan PEMBahasan}

Hasil pre-test menunjukkan bahwa miskonsepsi terjadi pada semua sub konsep suhu dan kalor seperti hubungan kalor dengan suhu, energi kinetik, massa jenis, tekanan, sub konsep pemuaian, aliran kalor, perubahan wujud zat hingga asas Black.

Pemberian perlakuan berupa pembelajaran dengan model pembelajaran perubahan konseptual, memberikan pengaruh positif pada siswa. Dari data hasil post-test siswa diketahui miskonsepsi masih terdapat pada semua sub materi namun dengan persentase yang lebih kecil dari sebelumnya yaitu dengan rata-rata $40,5 \%$ menjadi $23,1 \%$. Untuk memperjelas perbandingan miskonsepsi sebelum dan setelah pembelajaran, Peneliti sajikan dalam bentuk grafik pengurangan miskonsepsi siswa berikut ini:

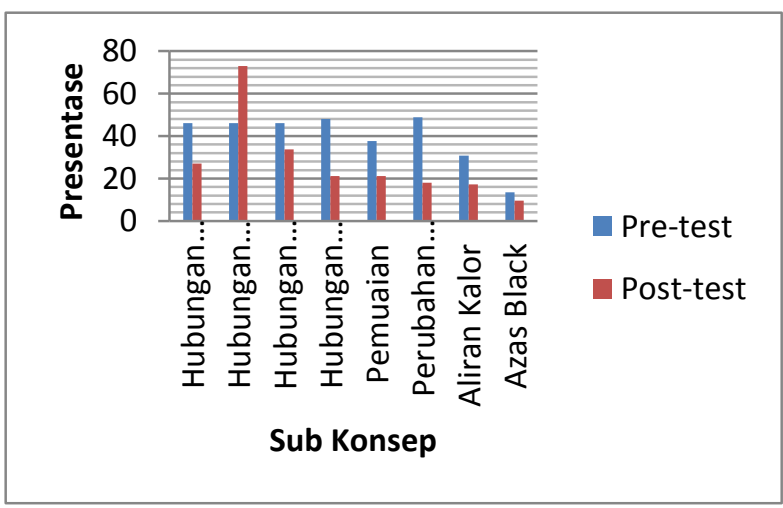

Gambar 1. Persentase Pengurangan Miskonsepsi Siswa

Sejalan dengan penurunan miskonsepsi maka pemahaman siswa pun meningkat, selengkapnya dapat dilihat pada grafik dibawah ini: 


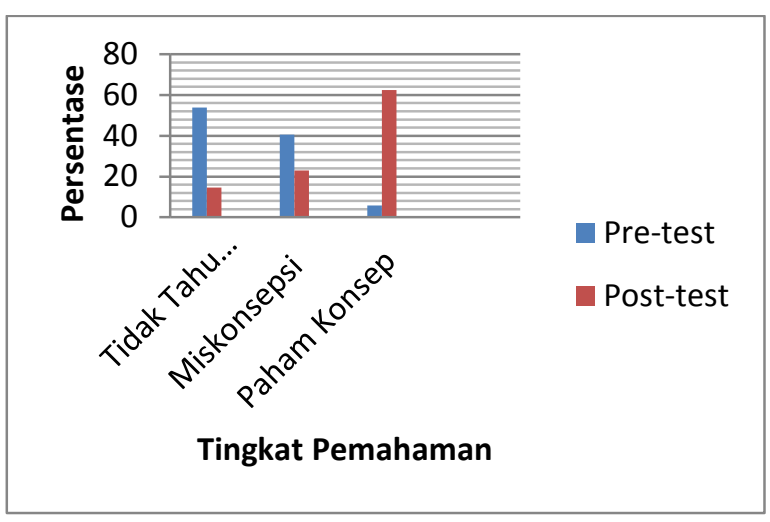

Gambar 2. Persentase Tingkat Pemahaman Siswa

Selama proses pembelajaran peneliti didampingi oleh guru mata pelajaran fisika yang bertindak sebagai observer yang menilai keterlaksanaan model pembelajaran perubahan konseptual sesuai dengan RPP yang disusun. Hasil analisis keterlaksanaan pembelajaran dengan model pembelajaran perubahan konseptual diperoleh dari skor yang diberikan observer pada lembar observasi yang dapat dilihat pada tabel di bawah ini.

Tabel 1. Persentase Keterlaksanaan Pembelajaran

\begin{tabular}{ccc}
\hline $\begin{array}{c}\text { Skor Yang } \\
\text { Diperoleh }\end{array}$ & $\begin{array}{c}\text { Skor } \\
\text { Ideal }\end{array}$ & Keterlaksanaan \\
\hline 21 & 26 & 81 \\
\hline
\end{tabular}

Analisis N-gain $\langle\mathrm{g}\rangle$ bertujuan untuk mengetahui bagaimana efektifitas model pembelajaran perubahan konseptual untuk mengatasi miskonsepsi siswa. Analisis N-gain $<\mathrm{g}>$ dilakukan berdasarkan pada skor yang diperoleh siswa sebelum dan setelah pembelajaran. Hasil analisis nilai $\mathrm{N}$-gain $\langle\mathrm{g}\rangle$ dapat dilihat pada tabel di bawah ini:

Tabel 2. Hasil N-gain $\langle\mathrm{g}\rangle$

\begin{tabular}{ccccccc}
\hline Tes & Skor & Skor & Skor & \multirow{2}{*}{ Rata-rata } & \multicolumn{2}{c}{$\langle\mathrm{g}\rangle$} \\
\cline { 6 - 8 } & Ideal & maksimum & minimum & & Nilai & Kriteria \\
\hline Pre-test & 50 & 21 & 5 & 13 & \multirow{2}{*}{0,65} & \multirow{2}{*}{ Sedang } \\
Post-test & 50 & 45 & 24 & 37 & & \\
\hline
\end{tabular}

Mata pelajaran fisika pada jenjang SMA memiliki beberapa tujuan, diantaranya adalah agar siswa memiliki pemahaman konsep dengan baik dan mampu menggunakannya dalam menyelesaikan berbagai permasalahan dalam kehidupan sehari-hari. Namun pada kenyataannya disekolah terdapat banyak kesalahan konsepsi (miskonsepsi) yang dialami siswa yang sangat menganggu bagi proses pembelajaran dan menghambat mereka dalam menyelesaikan berbagai permasalahan terkait konsep tersebut.

Dalam penelitian ini peneliti menerapkan model pembelajaran perubahan konseptual untuk mengatasi miskonsepsi fisika siswa, yaitu sebuah model pembelajaran yang berusaha mengatasi miskonsepsi siswa dengan cara melakukan konfrontasi terhadap miskonsepsi siswa melalui konflik kognitif

Penelitian ini dilaksanakan selama 9 kali pertemuan, pertemuan pertama peneliti memberikan pre-test untuk menjaring miskonsepsi siswa dan mengetahui konsep awal siswa. Pada pertemuan terahir peneliti memberikan post-test, untuk mengetahui apakah siswa masih mengalami miskonsepsi atau tidak.

Pemberian perlakuan berupa model pembelajaran perubahan konseptual dilakukan dalam tujuh kali pertemuan yang peneliti bagi kedalam tiga tahap (berdasarkan kompetensi dasar).
Tahap pertama dengan materi pengaruh kalor terhadap suatu zat.

Pada awal pertemuan siswa sangat tertarik dengan pertanyaan yang diberikan oleh guru dan mereka dengan antusias menjawab sesuai dengan konsepsi mereka. Saat guru melakukan sangkalan terhadap konsep siswa yang salah beberapa siswa justru mempertahankan konsep mereka, kemudian ketika guru melakukan demonstrasi yaitu menunjukkan hubungan antara kalor dengan suhu para siswa lebih tertarik pada alat-alat yang guru bawa, mereka merasa asing dengan alat tersebut maka guru harus menjelaskan tentang alat-alat tersebut terlebih dahulu sehingga waktu banyak tersita, hal ini menyebabkan beberapa proses yang ingin ditampilkan guru melalui demonstrasi tidak terlaksana sempurna karena waktu terbatas.

Tahap kedua dengan materi cara perpindahan kalor.

Pada tahap ini guru mengalami kesulitan dalam menentukan cara untuk menyampaikan konsep, sebab konsep ini lebih abstrak dari materi sebelumnya, terutama terkait dengan partikel-partikel penyusun zat dan hubungannya dengan kalor. Hal yang sama juga terjadi pada siswa, mereka kesulitan memahami tentang susunan partikel penyusun zat, pergerakan partikel (Ek) sebagai perantara panas dan perubahan susunan partikel akibat pengaruh kalor. Sehingga pada tahap ini guru berusaha semaksimal mungkin mengoptimalkan analogi dan contoh tandingan. 
Tahap ketiga dengan materi asas Black.

Pada tahap ini guru maupun siswa tidak mengalami kendala yang cukup berarti seperti pada tahap sebelumnya, mengingat materi ini adalah materi observable yang dapat diamati secara langsung oleh siswa melalui percobaan.

Selama pelaksanaan pengambilan data, peneliti di dampingi oleh guru mata pelajaran fisika yang sekaligus sebagai observer yang menilai keterlaksanaan model pembelajaran ini.

Berdasarkan hasil analisis data diperoleh persentase keterlaksanaan model pembelajaran perubahan konseptual ini adalah $81 \%$ atau tidak berjalan dengan sempurna dimana ada beberapa fase yang tidak terlaksana dengan sempurna hal ini tentu berpengaruh pada hasil belajar siswa sehingga diperoleh nilai gain $(\mathrm{G})$ atau keuntungan dari model pembelajaran ini dalam mengurangi miskonsepsi siswa adalah $17,5 \%$ dan nilai $\mathrm{N}$-gain $\langle\mathrm{g}\rangle$ adalah 0,65 tergolong dalam kriteria sedang. Hal ini menunjukkan bahwa model pembelajaran perubahan konseptual efektif untuk mengatasi miskonsepsi fisika siswa dengan kriteria sedang.

\section{Penutup}

Model pembelajaran perubahan konseptual dalam pelaksanaannya memerlukan sarana dan prasaran yang memadai, dan menuntut guru untuk aktif dan kreatif. Model ini efektif mengatasi miskonsepsi fisika siswa SMAN 1 Praya Barat tahun pelajaran 2012/2013 pada materi suhu dan kalor dengan criteria sedang.

Untuk mengatasi miskonsepsi fisika siswa guru bisa menjadikan model pembelajaran perubahan konseptual sebagai alternative. Dalam pelaksanaan model pembelajaran ini sebaiknya dipersiapkan dengan matang sehingga hasilnya dapat maksimal.

\section{REFERENSI}

[1] Departemen Pendidikan Nasional. 2006. Kurikulum Tingkat Satuan Pendidikan Sekolah Menengah Atas/Madrasah Aliyah. Jakarta: Departemen Pendidikan Nasional.

[2] Pertiwi, Dewinta. 2012. Penerapan Model Perubahan Konseptual Dengan Menggunakan Protype Media Berbasis Cmaptools (PMBCT) Untuk Megurangi Miskonsepsi Siswa SMP. Skripsi Sarjana pada FPMIPA UPI Bandung.

[3] Suparno, Paul. 2012. Filsafat Konstruktivisme dalam Pendidikan. Yogyakarta: Kanisius.
[4]

[5] Dahar, Ratna Wilis. 1996. Teori-Teori Belajar. Jakarta: Erlangga.

[6] Djamarah, Syaiful B. dan Zain,Aswan. 2006. Strategi Belajar Mengajar. Jakarta: Rieneka Cipta.

[7] Berg, E V D. 1991. Miskonsepsi Fisika dan Remediasi . Salatiga: Universitas Kristen Satya Wacana.

[8] Suparno, Paul. 2005. Miskonsepsi dan Perubahan Konsep Pendidikan Fisika. Jakarta: Grasindo.

\section{Biografi Penulis}

Dwi Pebriyanti, lahir di desa Penujak, kecamatan Praya Barat kabupaten Lombok Tengah NTB pada tanggal 8 Pebruari 1991, menempuh pendidikan dasar hingga pendidikan menegah di sekolah negeri di kecamatan Praya Barat kemudian melanjutkan pendidikan strata 1 tahun 2009 tepatnya pada Prodi Pendidikan Fisika FKIP UNRAM. Perempuan ini menyelesaikan pendidikannya dan meraih gelar sarjana pada bulan juni 2013 yang lalu. Sejak lulus gadis ini lansung mengajar di MA Ishlahul Ikhwan NW Mispalah Praya sebagai guru fisika dan matematika hingga saat ini. Gadis ini juga pernah bekerja sebagai staff pengumpul data di Summit Institut of Development selama 7 bulan pada tahun 2014, dan kini sedang sibuk mempersiapkan diri untuk melanjutkan pendidikan magister.

Dra. Hj. Hairunnisyah Sahidu, M.Pd lahir di Raba Bima, menyelesaikan pendidikan dasar di SDN 2 Raba, SMPN 1 Bima, melanjtkan sekolah menengah di SMA 1 Ciamis Jawa Barat. Gelar sarjana muda beiau perleh pada jurusan fisika IKIP Negeri Yogyakarta tahun 1997, gelar sarjana pada jurusan dan institute manajemen pendidikan, kemudian memperoleh gelar master pendidikan pada tahun 2004 di UNESA, Surabaya. Memulai karir di FKIP Universitas Mataram sejak tahun 1984 hingga saat ini. Jabatan fungsional saat ini lector kepala golongan ruang IVc dan membina beberapa mata kuliah diantaranya fisika dasar, mekanika, gelombang, optic, evaluasi pendidikan, strategi pembelajaran, metodologi penelitian, pendidikan pengembangan program pembelajaran fisika. Beliau juga kerap mengikuti diklat fungsional diantaranya metodologi penelitian AMDAL, calon penulis buku ajar, TPB bidang fisika di ITB, mekanika kuantum di UDAYANA, gelombang optik di UGM dan lain-lain. 